\title{
Bullae, bronchiectasis and nutritional emphysema in severe anorexia nervosa
}

\author{
Victoria J Cook MD ${ }^{1}$, Harvey O Coxson $\mathrm{PhD}^{1}$, Andrew G Mason $\mathrm{MD}^{2}$, Tony R Bai MD ${ }^{1}$ \\ ${ }^{1}$ Respiratory Division, Department of Medicine and ${ }^{2}$ Department of Radiology, \\ St Paul's Hospital, University of British Columbia, Vancouver, British Columbia
}

VJ Cook, HO Coxson, AG Mason, TR Bai. Bullae, bronchiectasis and nutritional emphysema in severe anorexia nervosa. Can Respir J 2001;8(5):361-365.

STUDY OBJECTIVES: Pulmonary complications of anorexia nervosa are rarely documented. The case of a patient with anorexia nervosa and pulmonary disease is presented, a new quantitative computed tomography (CT) method for the detection of emphysema is employed, the literature is reviewed and the concept of 'nutritional' emphysema is discussed.

RESULTS: The case of a 34-year-old, nonsmoking woman with long-standing severe anorexia nervosa who was evaluated for cough and progressive shortness of breath is reported. Pulmonary function testing showed a predominant restrictive pattern with a marked reduction in carbon monoxide transfer and respiratory muscle strength, and an elevated residual volume. Imaging revealed bullae and bronchiectasis, and quantitative analysis of the CT scan was consistent with mild, generalized emphysema. Bronchial washings grew Pseudomonas aeruginosa. Known causes for bronchiectasis were excluded. A literature review disclosed few reported noninfectious pulmonary complications of anorexia nervosa.

CONCLUSIONS: To the authors' knowledge, this is the first report of bullae and bronchiectasis in a patient with anorexia nervosa, and the $\mathrm{CT}$ analysis was consistent with mild emphysema. Malnutrition has been associated with emphysematous changes in animals and may be the primary insult in the development of emphysema, bullae and bronchiectasis in the present patient.

\section{Bulles, bronchiectasie et emphysème nutri- tionnel dans l'anorexie mentale grave}

OBJECTIFS DE L'ÉTUDE : Les complications pulmonaires de l'anorexie mentale sont rarement documentées. Le cas d'une patiente anorexique atteinte de maladie pulmonaire est présenté ici. On a eu recours à une nouvelle méthode de scintigraphie pour le dépistage de l'emphysème. La littérature est passée en revue, de même que le concept d'emphysème nutritionnel.

RÉSULTATS : On signale donc le cas d'une non-fumeuse de 34 ans présentant un problème d'anorexie mentale grave de longue date que l'on a examinée pour toux et essoufflement progressifs. Les épreuves de fonction pulmonaire ont montré un tableau surtout restrictif, avec réduction marquée du transfert du monoxyde de carbone, diminution de la force des muscles respiratoires et augmentation du volume résiduel. L'imagerie a révélé la présence de bulles et de bronchiectasie et l'analyse quantitative de la scintigraphie concordait avec un léger emphysème généralisé. L'analyse du liquide de lavage bronchique a révélé la présence de Pseudomonas aruginosa. Les causes connues de la bronchiectasie ont pu être écartées. Une revue de la littérature a permis d'identifier quelques complications non infectieuses associées à l'anorexie mentale.

CONCLUSION : À la connaissance des auteurs, il s'agit du premier cas signalé de bulles et de bronchiectasie chez une patiente atteinte d'anorexie mentale et l'analyse de la scintigraphie concordait avec un léger emphysème. La malnutrition a été associée à des anomalies de nature emphysémateuse chez des animaux et pourrait être le point de départ de l'emphysème bulleux et de la bronchiectasie chez cette patiente.

Key Words: Chronic obstructive pulmonary disease; Computed tomography; Malnutrition; Lung infections 
A norexia nervosa is a complex and devastating psychosocial disorder that is complicated by metabolic, immunological and endocrine abnormalities during the course of the disease. Of all psychiatric illnesses, it has the highest recorded morbidity and mortality rates. Anorexia nervosa is a disorder characterized by the tetrad of body weight less than $85 \%$ of expected, fear of weight gain, disturbance of body image and amenorrhea in postmenarchal females (1). It classically affects young, healthy, white, middle-class women. True prevalence and incidence statistics in North America are unknown, but prevalence has been quoted to be between $0.2 \%$ and $1 \%$ of the population, and incidence rates have been estimated annually at 7.3/100,000 population (1). The mortality rate in patients with anorexia nervosa is estimated at $0.6 \%$ year. The medical complications of anorexia nervosa are numerous, but pulmonary complications are rare and have not been acknowledged in a recent review (1). We recently encountered a patient with unexpected pulmonary complications, which prompted us to investigate the patient indepth and review the literature. Our investigations led us to re-present the notion of nutritional emphysema - an old but under-recognized concept.

\section{CASE PRESENTATION}

A 34-year-old white female patient with long-standing (longer than 16 years), severe anorexia nervosa of the restrictive subtype presented to St Paul's Hospital, University of British Columbia (Vancouver, British Columbia) with progressive shortness of breath and a productive cough. Her respiratory symptoms began at least one year before admission, when she noticed a dry cough. There was increasing shortness of breath on exertion, and weakness and fatigue, which limited her exercise tolerance to less than one block. Before this, she was a regular exerciser, walking hours per day without difficulty. Her cough became productive of creamy yellow sputum, 5 to $10 \mathrm{~mL} /$ day. Separate short courses of oral antibiotics did not change her symptoms. She denied hemop-

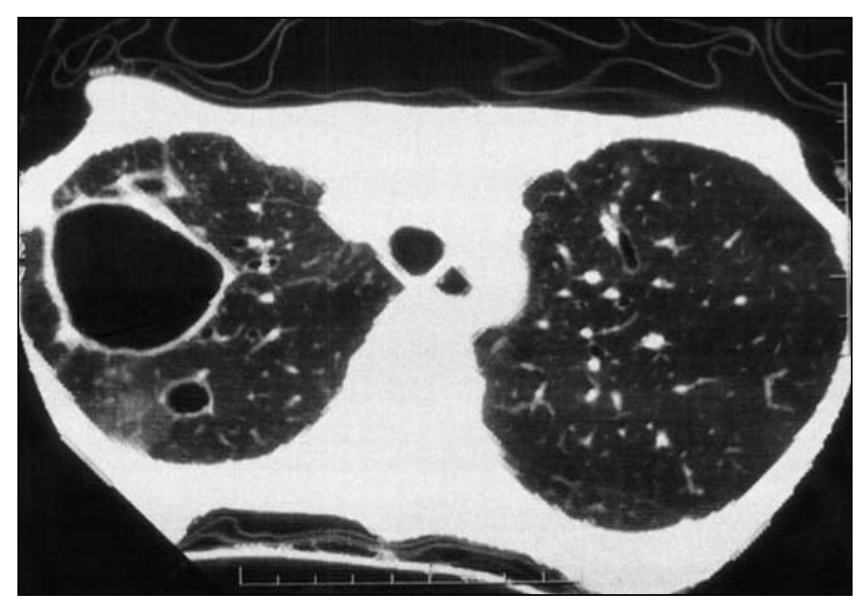

Figure 1) Computed tomography scan of the thorax in the present patient showing multiple bullae in the right upper lobe and cylindrical bronchiectasis in the anterior segment of the left upper lobe tysis, fever, chills and night sweats. She had no history of tuberculosis, recurrent pneumonia, or toxic exposures or inhalations. She was a lifelong nonsmoker, and denied alcohol and injection drug use. She had no significant travel history and was human immunodeficiency virus (HIV) negative. She had no history of recurrent sinusitis or middle ear problems. She denied purging behaviours, and she had no history of a seizure disorder to suggest aspiration. She kept two healthy budgerigars in her home. She had no known drug allergies, and her medications before admission included hormone supplements, vitamin and mineral supplements, docusate, cisapride and acetaminophen. The only family history of pulmonary disease was that she had a brother with asthma. She lived alone and worked as a pharmacy assistant. As part of previous research protocols of the nutrition service, she had had remote baseline pulmonary function tests and chest radiology.

On examination, she was severely cachectic, weighing only $26 \mathrm{~kg}$. Her height was $161 \mathrm{~cm}$, with a calculated body mass index of $10 \mathrm{~kg} / \mathrm{m}^{2}$. Her blood pressure was $100 / 50 \mathrm{mmHg}$, heart rate was 78 beats/min, respiratory rate was 12 breaths $/ \mathrm{min}$, temperature was $35.4^{\circ} \mathrm{C}$ and cutaneous oxygen saturation was $99 \%$ on room air. A head and neck examination showed small cervical lymph nodes. She was neither cyanosed nor clubbed. There was no accessory muscle use or evidence of hyperinflation. Percussion of the chest was normal. On auscultation, she was noted to have diffuse expiratory wheezes and inspiratory crackles localized over the right anterior chest and axillae. There was no bronchial breathing. Her cardiac, abdominal and neurological examinations were normal. Her skin showed multiple areas of breakdown, especially over the bony prominences of her feet. Investigations: The laboratory parameters showed: white blood cell count $6.7 \times 10^{9} / \mathrm{L}$ with normal differential, hemoglobin $74 \mathrm{~g} / \mathrm{L}$, mean corpuscular volume $95 \mathrm{mmol} / \mathrm{L}$, platelet count $469 \times 10^{9} / \mathrm{L}$, sodium $137 \mathrm{mmol} / \mathrm{L}$, potassium $3.9 \mathrm{mmol} / \mathrm{L}$, chloride $99 \mathrm{mmol} / \mathrm{L}$, bicarbonate $29 \mathrm{mmol} / \mathrm{L}$, urea $6.4 \mathrm{mmol} / \mathrm{L}$, creatinine $40 \mathrm{mmol} / \mathrm{L}$, phosphate $0.89 \mathrm{mmol} / \mathrm{L}$, calcium $2.24 \mathrm{mmol} / \mathrm{L}$ and magnesium $0.91 \mathrm{mmol} / \mathrm{L}$. Liver enzymes were mildly elevated (aspartate aminotransferase 66 units/L, alkaline phosphatase 157 units/L). Serum albumin was $36 \mathrm{~g} / \mathrm{L}$ (normal 35 to $50 \mathrm{~g} / \mathrm{L}$ ), and prealbumin was reduced at $104 \mathrm{mg} / \mathrm{L}$ (normal 200 to $420 \mathrm{mg} / \mathrm{L}$ ). Secretory immunoglobulin (Ig) A and alpha $_{1}$-antitrypsin levels and sweat tests were normal. Quantitative Ig tests showed normal IgM, mild elevation of $\mathrm{IgA}$ at $4.05 \mathrm{~g} / \mathrm{L}$ (normal 0.68 to $3.78 \mathrm{~g} / \mathrm{L}$ ), and normal $\mathrm{IgG}$ subclasses 1,3 and 4 , with mild elevation of subclass $\operatorname{IgG}_{2}$ at $7.77 \mathrm{~g} / \mathrm{L}$ (normal 1.17 to $7.47 \mathrm{~g} / \mathrm{L}$ ). Intranasal biopsies showed normal cilial structure at electron microscopy.

A chest radiograph on admission revealed right upper lobe bullous changes and bilateral bronchial wall thickening that was essentially unchanged from appearances four months previously. Bullae were noted to be present on chest radiographs up to three years before admission. A computed tomography (CT) scan of the chest showed no significant 
TABLE 1

Quantitative computed tomography analysis for emphysema in the present patient compared with previously published values for control subjects and patients with mild emphysema on histological examination

\begin{tabular}{|c|c|c|c|c|c|}
\hline & $\begin{array}{l}\text { Median } \\
\text { inflation } \\
\text { (mL gas/ } \\
\text { g tissue) }\end{array}$ & $\begin{array}{c}\text { Voxels } \\
6.0 \text { to } \\
10.2 \mathrm{~mL} / \mathrm{g}^{*} \\
(\%)\end{array}$ & $\begin{array}{c}\text { Voxels } \\
\text { greater than } \\
{ }^{*} 10.2 \mathrm{~mL} / \mathrm{g}^{\dagger} \\
(\%)\end{array}$ & $\begin{array}{l}\text { Surface } \\
\text { area/ } \\
\text { Volume } \\
\left(\mathrm{cm}^{2} / \mathrm{mL}\right)\end{array}$ & $\begin{array}{c}\text { Surface } \\
\text { area }\left(\mathrm{m}^{2}\right)\end{array}$ \\
\hline \multicolumn{6}{|l|}{ Control } \\
\hline \multicolumn{6}{|c|}{ Mild emphysema } \\
\hline cohort & $5.8 \pm 0.3^{\ddagger}$ & $35 \pm 4^{\ddagger}$ & $13 \pm 1^{\ddagger}$ & $212 \pm 12^{\ddagger}$ & $119 \pm 3^{\ddagger}$ \\
\hline Patient & $6.8 \pm 1.3$ & 39 & 18 & 170 & 62 \\
\hline
\end{tabular}

lymphadenopathy and confirmed a large right apical thickwalled bulla larger than $6 \mathrm{~cm}$ in diameter, with smaller adjacent bullae (Figure 1). Numerous nodular densities were noted in the lung zones diffusely, primarily centrilobular, with characteristic tree-in-bud forms consistent with retained small airway secretions. Dilated peripheral airways and bronchial wall thickening indicative of cylindrical bronchiectasis were noted bilaterally in both upper and lower lobes.

A new CT quantitative technique developed at the University of British Columbia, which has been used successfully to predict lung surface-to-volume ratio and surface area, and correlates with emphysema, was then used $(2,3)$. Computer images were obtained using a high resolution CT scanning technique with a field of view of $25.5 \mathrm{~cm}$, a thickness of $0.1 \mathrm{~cm}$ and a gap of $1.0 \mathrm{~cm}$ on a GE 9800 Highlight Advantage (GE Medical Systems, USA) CT scanner. The lung parenchyma, excluding the bullae, and the major vessels and airways were analyzed. The patient's lung surface-to-volume ratios were compared with values published from the University of British Columbia for control patients and patients with mild emphysema (2). The values determined for the present patient were suggestive of mild emphysema, because by definition, greater than $5 \%$ but less than $20 \%$ of her lung voxels were above $10.2 \mathrm{~mL} / \mathrm{g}$ (Table 1 ).

Pulmonary function studies (Table 2) were performed using standard techniques and compared with results obtained on the same apparatus in 1993. Residual volume was determined using the helium dilution technique, and single-breath diffusion capacity of the lung for carbon dioxide (DLCO) was measured in duplicate and corrected for anemia. The patient refused body plethysmographic measurement of lung volumes. Testing followed the standards of the American Thoracic Society. The results showed a predominantly restrictive pattern, with reduction in vital capacity and total lung capacity. Residual volume was increased both in 1993 and 1999, suggesting early airway closure or muscle
TABLE 2

Pulmonary function test results in our patient in 1993 and 1999

\begin{tabular}{lcccc}
\hline & $\begin{array}{c}1993 \\
\text { (weight 29 kg), } \\
\text { actual }\end{array}$ & $\begin{array}{c}\text { 1993, } \\
\text { \% predicted }\end{array}$ & $\begin{array}{c}1999 \\
\text { (weight 25 kg), } \\
\text { actual }\end{array}$ & $\begin{array}{c}\text { 1999, } \\
\text { \% predicted }\end{array}$ \\
\hline FVC & 2.37 & 63 & 1.35 & 38 \\
FEV $_{1}{ }^{*}$ & 2.20 & 67 & 1.20 & 40 \\
FEV $_{1} / \mathrm{FVC}$ & 0.93 & & 0.89 & \\
SVC & 2.34 & 62 & 1.38 & 39 \\
FRC & 2.71 & 80 & 2.47 & 73 \\
RV & 2.21 & 140 & 1.95 & 125 \\
TLC & 4.55 & 85 & 3.33 & 65 \\
DLCO & $16.39^{\dagger}$ & 65 & $8.97^{\ddagger}$ & 37 \\
DL/VA & 4.34 & 74 & 3.24 & 51 \\
\hline
\end{tabular}

${ }^{*}$ No response to bronchodilator; ${ }^{\dagger}$ Corrected for a hemoglobin of $70 \mathrm{~g} / \mathrm{L}$; ${ }^{\ddagger}$ Corrected for a hemoglobin of $80 \mathrm{~g} / \mathrm{L}$, using a formula from reference 26. See text for respiratory muscle testing results in 1999. $D L$ Diffusion capacity of the lung; DLCO Diffusion capacity of the

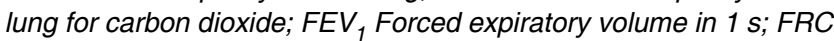
Functional residual capacity; FVC Forced vital capacity; $R V$ Residual volume; SVC Slow vital capacity; TLC Total lung capacity; VA Alveolar volume

weakness. There was no response to bronchodilators, and the flow-volume curve did not suggest expiratory airflow obstruction. DLCO corrected for her level of anemia was markedly reduced, more so than in 1993. Respiratory muscle testing showed a marked reduction in maximal inspiratory and expiratory muscle force (maximum inspiratory pressure $22 \mathrm{~cm} \mathrm{H}_{2} 0$, maximum expiratory pressure $34 \mathrm{~cm} \mathrm{H}_{2} 0$ ).

At bronchoscopy, marked pallor and apparent thinning of the bronchial mucosa was noted, but there was no endobronchial obstruction. The bronchoalveolar lavage specimen showed a marked polymorphonuclear cell increase, along with reactive columnar epithelial cells. Bronchial washings grew Pseudomonas aeruginosa, and treatment was started with intravenous ceftazidime for two weeks and then oral ciprofloxacin to complete six weeks of therapy. Mycobacterial cultures were negative.

\section{DISCUSSION}

Pulmonary complications of anorexia nervosa are rarely reported in the literature, and to our knowledge, this is the first report of bullae underlying emphysema and bronchiectasis. Although a causal relationship has yet to be determined, we propose that these complications are secondary to the severe prolonged malnutrition evident in our patient.

The results of experiments in protein-restricted rats show histopathological changes consistent with emphysema (4,5), a concept referred to as 'nutritional emphysema'. Starvation also worsens existing emphysema in rats. In the Warsaw, Poland ghettos during World War II, autopsy studies showed emphysema in malnourished young adults without any underlying lung disease or history to explain these changes (6). In our patient, there is evidence for emphysema on pulmonary function testing, as seen in the reduced 
DLCO tests and on quantification of lung surface area by CT scan. A recent report of pulmonary function testing in a cohort of patients with anorexia nervosa (7) showed decreased inspiratory and expiratory muscle strength and increased residual volume, as in our patient, but normal DLCO. However, we documented a marked diffusion abnormality even when corrected for hemoglobin and alveolar volume. The reduction in diffusing capacity, combined with the CT abnormalities, suggests a significant loss of alveolar capillary surface area consistent with the parenchymal destruction of emphysema. Our patient had a much longer duration of severe anorexia than the patients studied by Pieters et al (7), who had a median duration of illness of only 4.5 months.

Although the elevated residual volume may be secondary to expiratory muscle weakness alone, a component secondary to early closure of small airways accompanying early emphysema cannot be excluded. An apparent reduction in respiratory rate, tidal volume and oxygen consumption, as well as a weakness of the muscles of respiration, has been reported by others (8). In addition, a patient with severe hypophosphatemia from anorexia nervosa has been described, which manifested as generalized muscle weakness and bulbar muscle dysfunction, resulting in aspiration and cardiorespiratory arrest (9). Pneumomediastinum, subcutaneous emphysema, epidural emphysema and interstitial emphysema have all been reported in anorexia nervosa (10-12). Pneumomediastinum secondary to esophageal tears from excessive vomiting has also been reported. How malnutrition alters the lung parenchyma is unknown. Malnutrition leading to weakness of the alveolar wall and eventual rupture is the proposed mechanism in reports of soft tissue emphysema seen in anorexia nervosa $(10,11)$. An inflammatory cell influx in a milieu of imbalance between proteinases and antiproteinase activity probably causes the destruction of alveolar walls in emphysema due to tobacco smoking. There is evidence suggesting that there are antioxidant deficiencies, reduced numbers of functioning alveolar macrophages, and reduced production and secretion of surfactant in anorexia nervosa and other dietary disorders $(13,14)$. In the HIV population, there are reports of emphysematous-like changes in the lungs of patients without underlying lung disease (15). However, these patients also had severe wasting, so that the emphysematous changes may be, in part, related to malnutrition, although virus-induced changes may be more important in this group. HIV is also associated with bronchial dilation (16) and premature bullous disease $(17,18)$.

By examining the patient's history, physical well-being and laboratory studies, we were unable to link any of the common causes of bronchiectasis with our patient. Related to the binging and purging behaviours seen in some patients with anorexia nervosa, there have been reports of aspiration pneumonitis or pneumonia (19). Our patient gave no history of recurrent pulmonary infection and denied purging, and bronchiectasis after focal pneumonia was thought to be less likely because of the diffuse changes seen on the CT scan. She had no detectable abnormality in host defenses: her cil- ial structure and sweat test results, and her quantitative Ig, alpha ${ }_{1}$-antitrypsin and secretory IgA levels were normal. However, we have not ruled out a mild mutation in the CFTR gene that could predispose the patient to bronchiectasis in the presence of a normal sweat chloride. Also, T-cell function was not formally assessed, but total leukocyte counts and differential were normal. At the time of presentation, her airways were colonized with $P$ aeruginosa. We suspect that this pathogen, although capable of causing necrotizing pneumonia, was not responsible for her bullae, because these were noted on chest radiography two years before the onset of symptoms, although it is possible that the bullae were a consequence of subacute infection by Gramnegative organisms such as $P$ aeruginosa. Of note, her foot ulcers did not grow $P$ aeruginosa.

The immune status of patients with anorexia nervosa is an area of conflict in the literature. Hematological and immunological abnormalities such as bone marrow hypoplasia and neutropenia, reversible granulocyte bactericidal defects, hypocomplementemia, cutaneous anergy and elevated cortisol have all been documented in patients with anorexia nervosa $(13,20,21)$. However, despite documentation of low levels of Igs and complement, functional responses of patients with anorexia nervosa seem well preserved, in that serious infections are rare, particularly viral infections, and there has been no documented increased incidence of community-acquired pneumonia or opportunistic infections. One possible explanation is that anorexia nervosa is a carbohydrate-deficient state with adequate protein stores, whereas infection related to malnutrition is well documented in protein-calorie malnutrition, as seen in patients with kwashiorkor, who have low levels of cell-mediated and humoralmediated immunity $(22,23)$. However, it has been postulated that anorexia nervosa may predipose patients to unusual infections with organisms of lower pathogenicity, such as the Pseudomonas species seen in our patient (13).

Tuberculous disease is the most common pulmonary infection linked to anorexia nervosa $(1,21,24)$. Nontuberculous mycobacterial infection has also been reported (20). Impaired ventilatory responses during starvation have been hypothesized to contribute to the increase in tuberculosis seen in these patients (13), although compromised cellmediated immunity is more likely to be responsible (25).

\section{CONCLUSIONS}

We present evidence that the malnourished state associated with anorexia nervosa negatively affects the respiratory system. The present patient is likely to be at an increased risk for further pulmonary complications such as pneumothorax and recurrent infections. The concept of nutritional emphysema in this patient population could be further established in a cohort of patients with various degrees of malnutrition using the $\mathrm{CT}$ approach outlined above.

ACKNOWLEDGEMENTS: The authors' research is supported by the British Columbia Lung Association. 


\section{REFERENCES}

1. Becker AE, Grinspoon SK, Klibanski A, et al. Eating disorders. N Engl J Med 1999;340:1092-8.

2. Coxson HO, Rogers RM, Whittall KP, et al. Quantification of the lung surface area in emphysema using computed tomography. Am J Respir Crit Care Med 1999;159:851-6.

3. Muller NL, Staples CA, Miller RR, et al. Density mask: an objective method to quantitate emphysema using computed tomography. Chest 1988;94:782-7.

4. Sahebjami H, Wirman A. Emphysema-like changes in the lungs of starved rats. Am Rev Respir Dis 1981;124:619-24.

5. Sahebjami H, Domino M. Effects of starvation and refeeding on elastase-induced emphysema. J Appl Physiol 1989;66:2611-6.

6. Stein J, Fenigstein H. Anatomie pathologique de la maladie de famine. In: Apfelbaum E, ed. Maladie de Famine. Recherchers Clinique sur la Famine Executees dans le Ghetto de Varsovie en 1942. Paris: American Joint Distribution Committee, 1946:21-7.

7. Pieters T, Boland B, Beguin C, et al. Lung function study and diffusion capacity in anorexia nervosa. J Intern Med 2000;248:137-42.

8. Lands L, Desmond KJ, Demizio D, et al. The effects of nutritional status and hyperinflation on respiratory muscle strength in children and young adults. Am Rev Respir Dis 1990;141:1506-9.

9. Cariem AK, Lemmer ER, Adams MG, et al. Severe hypophosphatemia in anorexia nervosa. Postgrad Med J 1994;70:825-7.

10. Satoh K, Ohkawa M, Tanabe M, et al. Anorexia nervosa with soft-tissue emphysema in multiple locations. AJR Am J Roentgenol 1994;163:484.

11. Satoh K, Kawase Y, Kobayashi T, et al. Anorexia nervosa; an association with certain types of soft-tissue emphysema. Nihon Kyobu Shikkan Gakkai Zasshi 1994;32:685-8.

12. Lewis MI, Monn SA, Zhan WZ, et al. Interactive effects of emphysema and malnutrition on diaphragm structure and function. J Appl Physiol 1994;77:947-55.

13. Tenholder MF, Pike JD. Effect of anorexia nervosa on pulmonary immunocompetence. South Med J 1991;84:1188-91.

14. Riley DJ, Thakker-Varia S. Effect of diet on lung structure, connective tissue metabolism and gene expression. J Nutr 1995;125(Suppl 6): 1657S-60S.

15. Diaz PT, Clanton TL, Pacht ER. Emphysema-like pulmonary disease associated with human immunodeficiency virus infection. Ann Intern Med 1992;116:124-8.

16. King MA, Neal DE, St. John R, et al. Bronchial dilatation in patients with HIV infection: CT assessment and correlation with pulmonary function tests and findings at bronchoalveolar lavage. Am J Radiol 1997;168:1535-40.

17. Kuhlman JE, Knowles MC, Fishman EK, et al. Premature bullous pulmonary damage in AIDS: CT diagnosis. Radiology 1989;173:23-2.

18. Gurney JW, Bates FT. Pulmonary cystic disease: comparison of Pneumocystis carinii pneumatoceles and bullous emphysema due to intravenous drug abuse. Radiology 1989;173:27-31.

19. Ferguson GT, Miller YE. Occult mineral oil pneumonitis in anorexia nervosa. West J Med 1988;148:211-3.

20. Brown GR. Anorexia nervosa complicated by Mycobacterium xenopi pulmonary infection. J Nerv Mental Dis 1987;175:629-32.

21. Gupta K, Sivakumar K. Anorexia nervosa and tuberculosis: case reports and a review of immune mechanisms. Int J Eat Disord 1994;15:301-4.

22. Boss LP, Toole MJ, Yip R. Assessments of mortality, morbidity, and nutritional status in Somalia during the 1991-1992 famine: recommendations for standardization of methods. JAMA 1994;272:371-6.

23. Moore PS, Marfin AA, Quenemoen LE. Mortality rates in displaced and resident populations of central Somalia during 1992 famine. Lancet 1993;341:935-8.

24. Ishii Y, Yoneda T, Tsukaguchi K, et al. Anorexia nervosa complicated with pulmonary tuberculosis. Kekkaku 1994;69:71-5.

25. Szabo CP. Tuberculosis and anorexia nervosa. S Afr Med J 1998;88:275-6.

26. Clark EH, Woods RL, Hughes JMB. Effect of blood transfusion on the carbon monoxide transfer factor in men. Clin Sci 1978:54:627-31. 


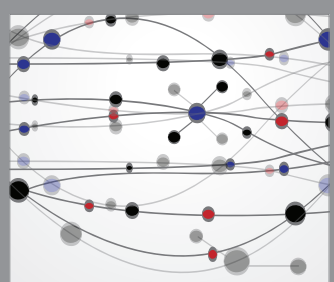

The Scientific World Journal
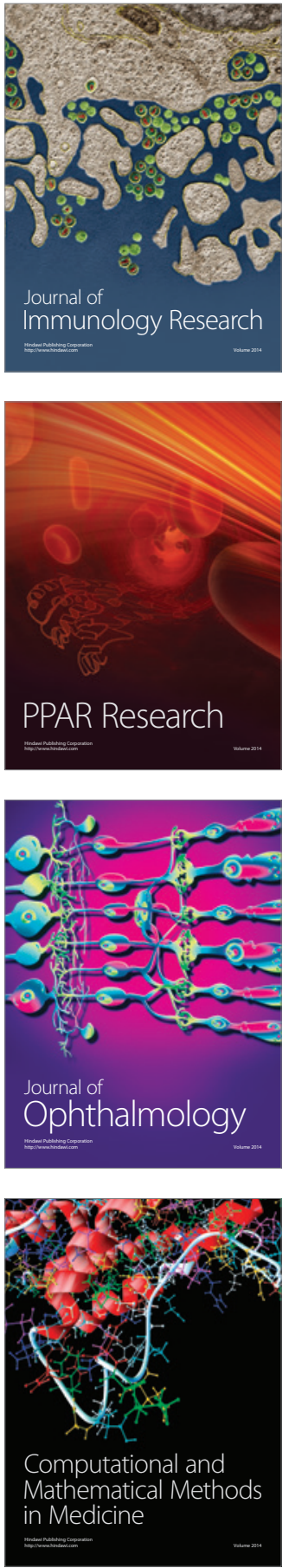

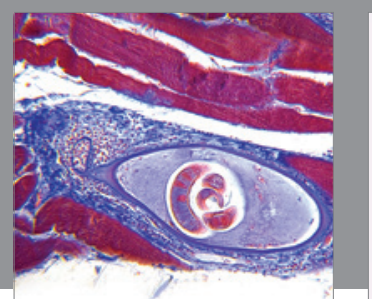

Gastroenterology Research and Practice

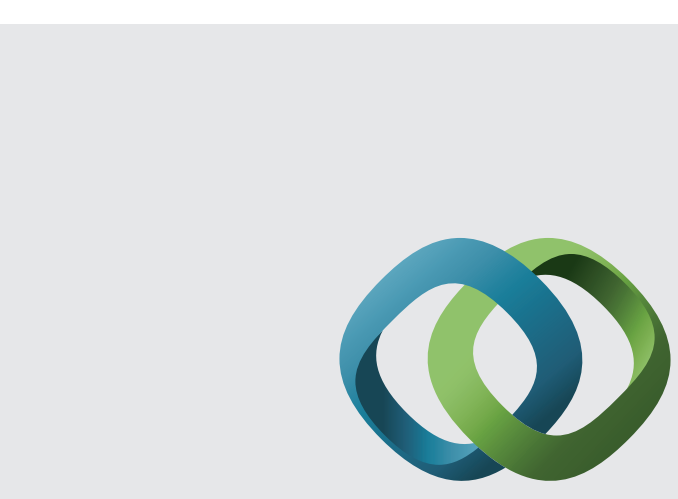

\section{Hindawi}

Submit your manuscripts at

http://www.hindawi.com
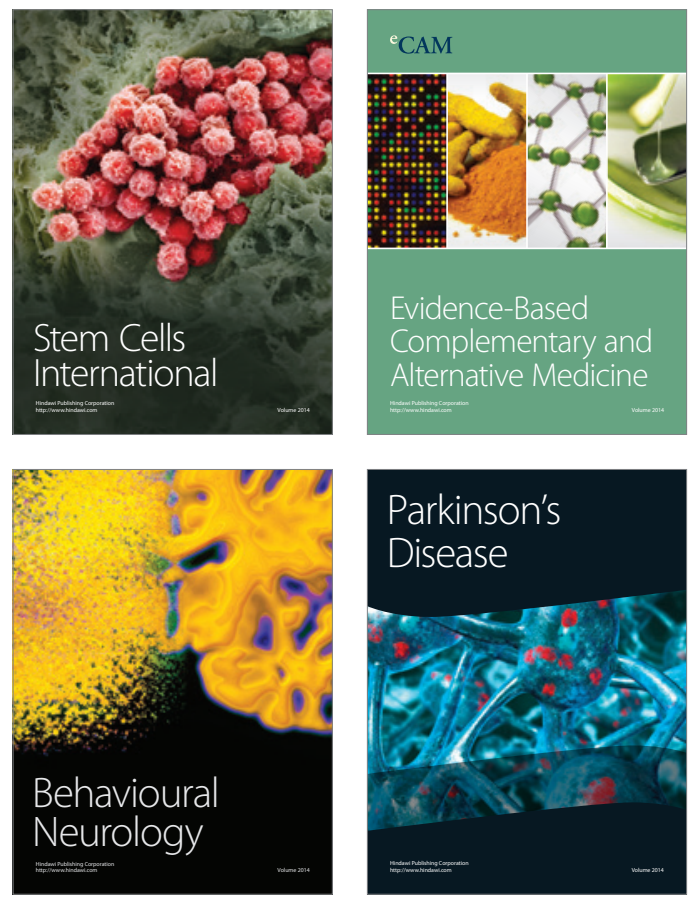
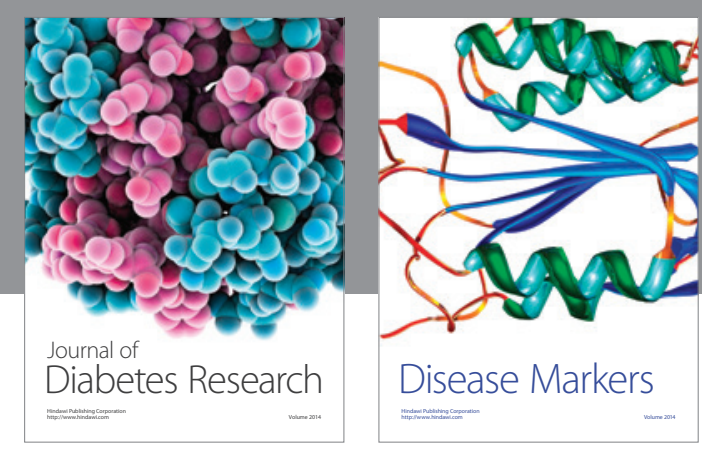

Disease Markers
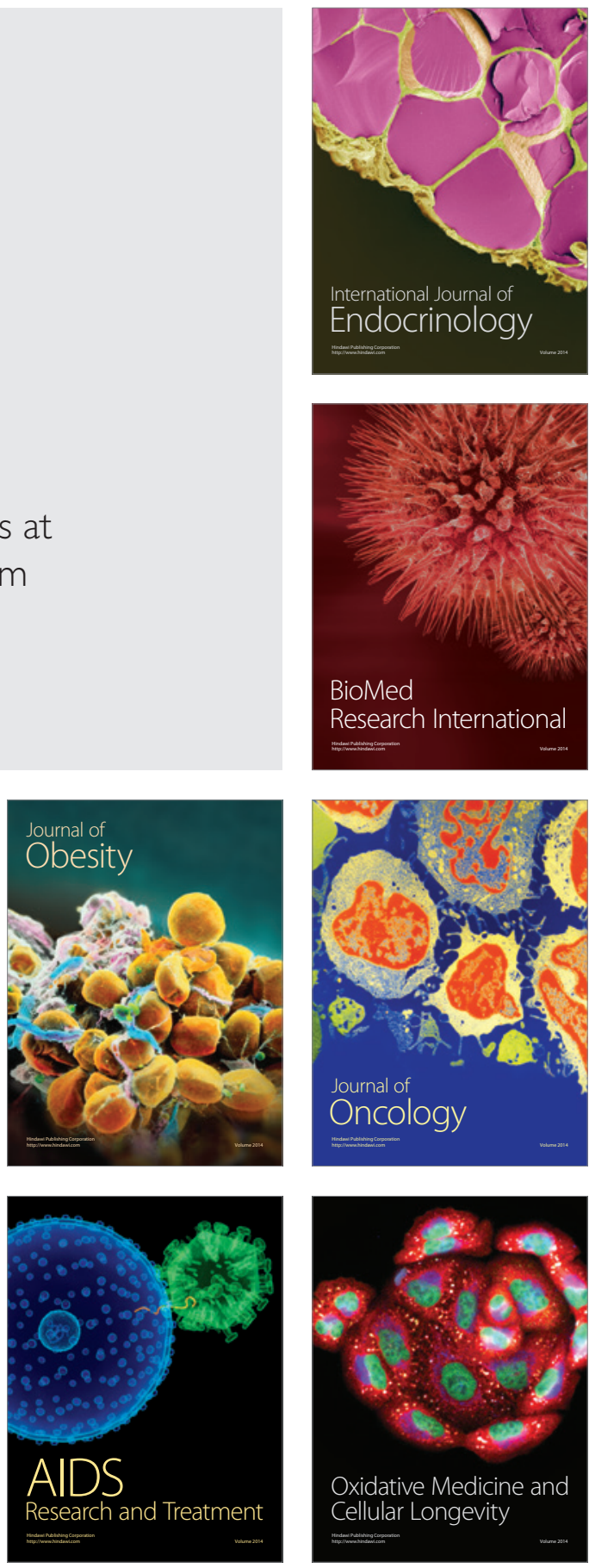